\title{
PREDICTING RETAIL BANKING CONSUMER BEHAVIOUR USING STATISTICS
}

\author{
Konstantinos Agaliotis ${ }^{1,}{ }^{*}$, Miroljub Hadžić ${ }^{2}$ \\ ${ }^{1}$ Alpha Bank ad, Belgrade, Member of EB \\ 11 Kralja Milana Street, Belgrade, Serbia \\ ${ }^{2}$ Singidunum University, Faculty of Business \\ 32 Danijelova Street, Belgrade, Serbia
}

\begin{abstract}
:
The purpose of any economic-based activity is the creation of needs. As the financial activities are not an exception to this rule, understanding clients' necessities and their satisfaction is of primary concern for all financial institutions. Being conversant with the exact details that constitute client behaviour and the processes that lead to particular decisions, has become an advantage for financial institutions investing resources in it. Finally, it will not only pay off by satisfying the clients' needs, but it will also secure a long-standing loyalty and relationships with them. As all relationships, the one between the client and the bank requires support and mutual understanding.

Given the Serbian retail banking market, we may conclude the following: firstly, there is still potential for doing business in this filed; secondly, the particular segments of customers would accept new products; and thirdly, banks have to focus on the highest ranking clients concerning their credit worthiness. As regards the client behaviour over different product offerings, we can conclude that cash loans and credit card holders are not price sensitive, and that subsequently, the existing holders intend to increase their credit exposure.
\end{abstract}

\section{Key words:}

retail banking,

clients behavior, segmentation, loyalty.

\section{INTRODUCTION}

The banking industry faces intense competition and the frequent shifting of customer base continues to be of primary concern. Focused customer segmentation for cross-selling and up-selling of products and services has become a necessity. Given the fierce competition and high customer attrition rate, modern banking requires efficient tools and means to promote products and services to the existing and prospective customers, increase revenue, improve customer loyalty, and thus strengthen customer base.
Provided that there is a system that could statistically predict sales behaviour of prospective customers, each institution may benefit immensely by allocating the available resources from Above the Line sales related activities, to one-on-one based personalized actions.

The research was focused on retail segment clients in Serbia with two aspects of the analysis. Namely, the first one refers to pre-selection of clients with the aim to find the least possible risky clients, on the one hand, and the most worthy ones, on the other hand. The second aspect refers to segmentation of clients 
in order to find the most attractive niche and create suitable product offer for them.

The assumptions consider the standard banking environment where the objective of each retail manager is to maximize profit at minimum cost. So, the starting hypothesis is as follows: customers will behave based on the standard patterns following the pre-defined calculation methodology.

The data used for the subject analysis consider only part of the retail banking business industry, i.e. overdrafts, consumer loans, housing loans and credit cards. Limitations might exist given the different credit policies applied by each financial institution running business in Serbia, as well as the different products' primary focus of each financial institution.

\section{PERSONAL SELLING AND MARKETING}

Although different industries have developed different selling strategies and approaches, the importance of personal selling still remains high. It is obvious that personal selling requires a two-way communication which in the case of a financial institution, includes an individual who aims at persuading the other individual to take the appropriate action (Brassington, 2010). The post purchase satisfaction cannot be ignored. It always serves as the base for building long and profitable relationships (Muller \& Nordman, 2004; Storbacka \& Nenonen, 2014; Storbacka \& Pennanen, 2014).

The marketing mix to support the personal selling depends on the parameters that define the particular consumers understanding and perception of services satisfaction (Ajzen, 2008). Many international banks see that there is no easy way to create marketing mix synergies, as standardization is always subject to different regulatory frames, cultures, languages and social perceptions.

For a bank, marketing is the concept of implementation and achievement with all available means and objectives, development of coherent and satisfying market segments, determined and selected in advance (Kumar, 2013; Rose \& Hudgins, 2013).

In the second half of the 20th century, the entire retail banking industry profile changed due to diversified banking services, by engaging in some operations formerly incumbent of specialized banks, as well as by the provision of new services in border areas with other financial operators.

This extension of banking services aimed obviously at profit, but simultaneously, sought to assist the clients, providing them with the access to useful and desirable services. Around the 1970s, banks developed programs to support businesses and widely promote banking products and services to meet customer requirements.

\section{THE PLANNED BEHAVIOUR THEORY}

The planned behaviour theory (TPB) is designed to predict and explain human behaviour within a certain framework. It was initiated in 1991 by Icek Ajzen as an extension of the reasoned action theory due to its limitations, i.e. failing to explain behaviours over which humans had limited volitional control (Godin \& Kok, 2001; Conner \& Armitage, 2001).

The main element is one's intention to adapt certain behaviour. The intentions are recognised as the steaming power influencing behaviour, and they are the best effort indicators for humans who are about to take seriously a "call to action". The adaptation of the majority of behaviours depends to a certain extent on the so called no generating factors which translate into the availability of opportunities and resources (Miller, 1956). These can be time, money, competences, cooperation with other etc. (Ajzen, 1991; Ajzen, 2002; Ajzen, 2008). Such parameters represent the real control of the human over the behaviour. If a human has the necessary opportunities and money, and intends to adapt behaviour, then he/she should succeed in doing so (Fishbein, 1979; Raz, 2010).

The TPB sets three independent terms as the basics elements of the intentions. The first is the attitude towards the behaviour, referring to the degree to which one considers positively or not the subject behaviour. The second characteristic is the subjective norm that refers to the perceived social pressure for the adaptation of certain behaviour. The third characteristic is the level of the perceived behavioural control (Campbell \& Russo, 2001; Farr, 1994; Read \& Miller, 2014).

The perceived behavioural control is very important for TPB. The perceived behavioural control refers to one's understanding of easiness or difficulty to adapt behaviour. The perceived behavioural control differs given different situations and environments. Therefore, it might be the case for a human to believe that results mostly depend on his/her personal behaviour, but at the same time, to believe that the possibilities to adapt the anticipated behaviour are low (Ajzen, 1991; Ajzen \& Fishbein, 2010).

A generic rule applying in TPB is that the more favourable the attitude and the subjective norms to the behaviour, the higher the perceived control is, in 


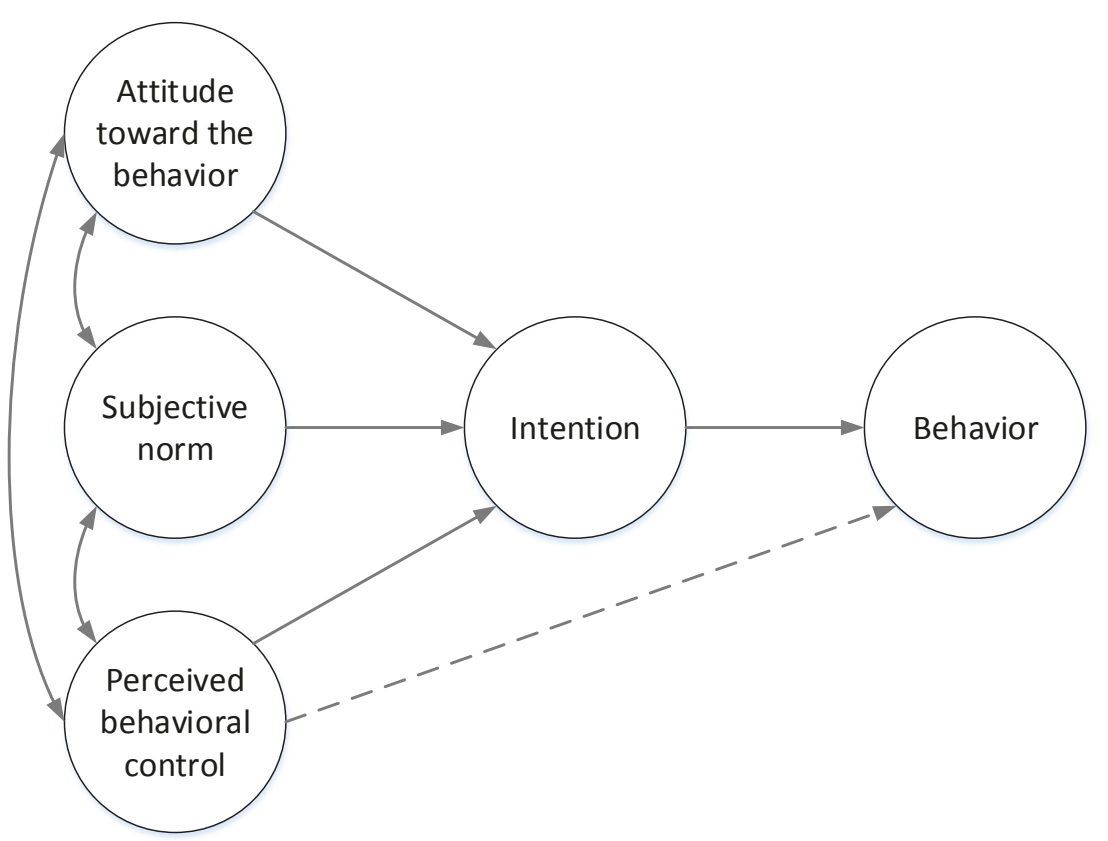

Figure 1. Theory of planned behaviour

Source: Ajzen (1991)

which case the intention of an individual to adapt certain behaviour becomes very possible.

According to TPB, the adaptation of behaviour is a function that links the intentions with the behavioural perceived control (Armitage \& Conner, 2001).

\section{SALES: CREDIT WORTHINESS AND SELECTION OF PRE-APPROVED CLIENTS}

A large volume of data was examined using primarily the "over-underrepresentation" theory that intends to identify the propensity of clients to react positively to a bank's offer. Using the data that segment the same customers' universe before and after the particular product offerings, we identified the likelihood of customers to either reply positively to a new product offering, or reply positively to a counter offer aiming to retain potential defectors.

The first step considered all prospects being analysed primarily for their credit worthiness, and subject to their eligibility, for their willingness to apply for another product. The ability of a financial institution to penetrate the whole of a particular market is not to be overlooked. The credit worthiness eligibility of the entire Serbian population is indicatively used in order to identify the credit potentials of the whole market before entering into a behavioural analysis.
The "propensity to buy/defect" approach was also supported by the full operational analysis of the product/service offer effort, as we do not stay only at the willingness level of the clients, but we sought to identify the efficiency of all steps mediating from the positive answer of clients up to the final credit disbursement/client retention by means of a mathematical model.

The business case focuses on particular products of a retail banking environment, i.e. credit cards, personal loans, debt consolidation loans and overdrafts.

It is of paramount importance to detect the possibilities to "enter" an overall market. The analysis which assesses the creditworthiness of the entire population of a country, characterizing it as "bankable" or not, is essential for understanding the market perspectives, but also for positioning retail banking products using different priorities set. The criteria used for assessing the eligibility of the prospects were: Employment Status-Age-Income-Availability of Fixed phone number-Credit Bureau historic and current delays-Debt to Income Ratio-Pool Scorecard and Internal Grading. The following analysis was applied to the entire Serbian population in August 2014.

It can be seen that in a certain population of $7,181,505$ inhabitants of Serbia, 908,000 make up the potential "bankable population". The most noticeable results can be divided in two groups, the employed 
and the pensioners' prospects. When it comes to the former one, the exclusion criteria with the higher percentages are credit bureau delays (36.5\%), DTI/ Scoring (29\%), employment (24\%), income (13.5\%) and age (11.5\%).

The higher exclusion criteria for the latter are income $(29.2 \%)$, age (27.3\%), credit bureau delays (26\%) and DTI/Scoring (22\%).
An in-depth one-to-one comparison between the employed individuals and pensioners needs to rely on many aspects, such as the structure of the economy, the historic evolution of public $v s$. private sector, the compensation strategy of the country, the infrastructure etc. A snapshot approach could definitely observe that the pensioners tend to be relatively more credit worthy based on the criteria that they can really in-

\begin{tabular}{|c|c|c|c|c|c|c|c|c|c|c|c|}
\hline \multirow{3}{*}{ 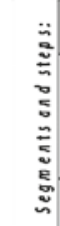 } & \multicolumn{11}{|c|}{ Bankable Population - Results } \\
\hline & & & Belgrade & Vojvodina & $\begin{array}{c}\text { Central \& } \\
\text { Western } \\
\text { Serbia }\end{array}$ & $\begin{array}{c}\text { Southern \& } \\
\text { Eastern } \\
\text { Serbia }\end{array}$ & Total & & Share & Criteria & $\begin{array}{l}\text { Isolated } \\
\text { effect }\end{array}$ \\
\hline & \multicolumn{2}{|l|}{ Total population } & $1,660,156$ & $1,917,325$ & $2,013,322$ & $1,590,702$ & $7,181,505$ & & $100 \%$ & & \\
\hline A. & Employed population & & 564,702 & 446,184 & 403,358 & 305,756 & $1,720,000$ & & $24 . \%$ & & \\
\hline \multirow[t]{4}{*}{ B. } & Pensioners & & 402,476 & 437,235 & 455,312 & 383,037 & $1,688,060$ & & $23.5 \%$ & & \\
\hline & Total bankable population - employed + pensioners: & & 277,000 & 263,500 & 197,000 & 170,500 & 908,000 & & & & \\
\hline & & & \multicolumn{5}{|c|}{ \%of Total population: } & & $12.6 \%$ & & \\
\hline & & & \multicolumn{5}{|c|}{ \%of Employed + Pensioners: } & & $26.6 \%$ & & \\
\hline A. & Employed & & & & & & & & 8 & & \\
\hline \multirow[t]{2}{*}{ step 1: } & No of employed people & & 564,702 & 445,184 & 403,358 & 305,756 & $1,720,000$ & & $100 \%$ & & \\
\hline & ABSclients-emploied & & $4 \%$ & $3 \%$ & $3 \%$ & $6 \%$ & $.72,438$ & & $4.2 \%$ & ABSClients & 4.23 \\
\hline \multirow[t]{2}{*}{ Step2: } & Employed/ new clients: & & 539,574 & 431,004 & $389, A 14$ & 287,570 & $1,647,562$ & & $95.8 \%$ & & \\
\hline & ¿x of employed - aged 20-57: & & $88 \%$ & $88 \%$ & $83 \%$ & $88 \%$ & $-197,085$ & & $11.5 \%$ & Age & $-11.5 \%$ \\
\hline \multirow[t]{2}{*}{ step 3: } & Employed/ new clients / age 20-67 & & 475,029 & 379,446 & 342831 & 253,170 & $1,450,476$ & & $84.3 \%$ & & \\
\hline & Fi d popu ation with fxed phone: & & $92 \%$ & $92 \%$ & $92 \%$ & $92 \%$ & $-115,038$ & & $6.7 \%$ & Phone & $-6.7 \%$ \\
\hline \multirow[t]{2}{*}{ step 4: } & Employed/ new clients / age 20.67/ fived phone & & 437,026 & 349,090 & 315,405 & 232,916 & $1,334,438$ & & $77.6 \%$ & & \\
\hline & \%o of employed - aged 20.57 - with salary $20 \mathrm{kt}$ : & & $88 \%$ & $84 \%$ & $73 \%$ & $76 \%$ & $.231,613$ & & $13.5 \%$ & Salay & $\cdot 13.5 \%$ \\
\hline \multirow[t]{2}{*}{ step 5: } & Employed/ new clients / age 20-67/ fixed phone/ salary 20kt & & 386,505 & 292,944 & 246882 & 176,494 & $1,102,825$ & & $64.1 \%$ & & \\
\hline & 5 of employed - aged 20.57 - 5 alary $20 \mathrm{ke}$ with $C B \alpha$ & & $65 \%$ & $73 \%$ & $64 \%$ & $73 \%$ & $.347,037$ & & $20.2 \%$ & $C B$ & $.36 .5 \%$ \\
\hline \multirow[t]{7}{*}{ step 6: } & Employed/ new clients / age 20-57/ fixed phone/ salary 20k+ / CB ok & & 255,093 & 213,849 & 158,004 & 128,841 & 755,787 & & $43.9 \%$ & & \\
\hline & zis of (employed \& aged $20-57 \&$ salary $20 k+\& C B$ \&) with (DT \& Score) & $\%$ & & & & & & \multicolumn{2}{|c|}{ aceptoble } & \multirow{6}{*}{$\begin{array}{l}\text { Diland } \\
\text { Score }\end{array}$} & \\
\hline & out of which will apply for All In One & $25 \%$ & 63,773 & 53,462 & 39,501 & 32,210 & 188,947 & $67 \%$ & \multirow{5}{*}{$13 \%$} & & \multirow{5}{*}{$.29 \%$} \\
\hline & out of which will apply for Car loans & $2 \%$ & 5,102 & 4,277 & 3,160 & 2,577 & 15,116 & $90 \%$ & & & \\
\hline & out of which will apply for Cash Loans & $60 \%$ & 153,056 & 128,309 & 94,803 & 77,305 & 453,472 & $70 \%$ & & & \\
\hline & out of which will apply for Consumer lcans & $3 \%$ & 7,653 & 6,415 & 4,740 & 3,865 & 22,674 & $80 \%$ & & & \\
\hline & out of which will apply for Credt Cards & $10 \%$ & 25,509 & 21,385 & 15,800 & 12,884 & 75,579 & $75 \%$ & & & \\
\hline \multirow{2}{*}{$\begin{array}{l}\text { step 7: } \\
\text { B. }\end{array}$} & Bankable population - employees & $100 \%$ & 179,500 & 150,500 & 111,000 & 90,500 & 531,500 & & $30.9 \%$ & & \\
\hline & \multicolumn{7}{|l|}{ Pensimers } & & 8 & & \\
\hline \multirow[t]{2}{*}{ step 1: } & \multicolumn{2}{|l|}{ No of pensioners } & 402475 & 437,235 & 465,312 & 383,038 & $1,688,060$ & & $100 \%$ & & \\
\hline & \%o of pensioners - aged lowe than 20 and higher than 67 : & & & N & & & $1,227,253$ & & $72.7 \%$ & Age & $.27 .3 \%$ \\
\hline $\sec 2:$ & So d persioners - aged 20-67: & & 292,510 & 317,881 & 338,294 & 278,478 & $1,227,263$ & & $72.7 \%$ & & \\
\hline & ABSclients - pensioners & & $2 \%$ & $1 \%$ & $\%$ & $2 \%$ & $.19,051$ & & $1.1 \%$ & ABSClients & -1.11 \\
\hline step 3: & Pensioners / age 20-67 / new clients. & & 287,217 & 314,916 & 333,703 & 272,376 & $1,208,212$ & & $71.6 \%$ & & \\
\hline & \%o of popu ation with fixed phone: & & $92 \%$ & $92 \%$ & $92 \%$ & $92 \%$ & $.96,657$ & & $5.7 \%$ & Phone & $.5 .7 \%$ \\
\hline step 4: & Pensioners / new clients / age 20-67/ fxed phone & & 264,239 & 289,723 & 307,007 & 250,586 & $1,111,555$ & & $65.8 \%$ & & \\
\hline & 3 of persioners - persion $20 \mathrm{kt}$ : & & $62 \%$ & $60 \%$ & $50 \%$ & $51 \%$ & 492,288 & & $29.2 \%$ & Salary & .29 .2 \\
\hline step 5: & Pensioners / new clients / age 20-67/ foxed phone/ income 20kt & & $163 A 17$ & 173,066 & 154,050 & 128,734 & 619,267 & & $36.7 \%$ & & \\
\hline & \%o of popuation with CB delay & & $75 \%$ & $82 \%$ & $70 \%$ & $78 \%$ & $-145,542$ & & $8.7 \%$ & $C B$ & $-26.0 \%$ \\
\hline $\operatorname{stepe} 6:$ & Pensioners / new clients / age 20-67 / fixed phone/ income 20kt / CB ok & & 122,562 & 141,914 & 107,835 & 100,412 & 472,724 & & $28.0 \%$ & & \\
\hline & Fo d lpensioners \& aged 20.57 \& income 20k+ \& CB) with (DT \& Score) & $\%:$ & & & & & & acceptoble & & & \\
\hline & out of which will apply for All In One & $25 \%$ & 30,641 & 35,479 & 26.959 & 25,103 & 118,181 & $74 \%$ & & & \\
\hline & out of which will apply for Car Loans & $2 \%$ & $2,45:$ & 2,838 & 2,157 & 2,008 & 9,454 & $95 \%$ & & & \\
\hline & out of which will apply for Cash Loans & $60 \%$ & 73,537 & 85,249 & 64,701 & 60,247 & 283,634 & $83 \%$ & $6 \%$ & Diland & $.22 \%$ \\
\hline & out of which will apply for Consumer Lcans & $3 \%$ & 3,577 & 4,257 & 3,235 & 3,012 & 14,182 & $84 \%$ & & & \\
\hline & out of which will apply for Credt Cards & $10 \%$ & 12,256 & 14,191 & 10,784 & 10,041 & 47,272 & $71 \%$ & & & \\
\hline step 7: & Bankable population - pensioners & $100 \%$ & 97,500 & 113,000 & 86,000 & 80,000 & 376,500 & & $223 \%$ & & \\
\hline
\end{tabular}


fluence, see credit bureau delays and DTI/Scoring. Unlike these personal characteristics that indicate particular consumer behaviour towards credit repayments and social profile, both income and age criteria are "out of reach" and are not subject to behavioural changes.

\section{SALES: METHODOLOGY FOR PROPORTIONAL REPRESENTATION}

The subject methodology is based on the over/ under representation principle in order to prove that different client categories do not only have a higher propensity to buy (see inclination to reply positively to a product's offer), but also deliver the best final results compared to the resources used.

The methodology considers the percentage split of sub - segments between two similar micro societies. A simple example can be the professions or educational levels, which make up the existing portfolio of any clientele's database.

Should the percentage representing the profession "Teachers" remain the same between the clientele's database used for the selection of the prospects and the final disbursed credit list of clients, we may come to the conclusion that "Teachers" are not influenced by the subject product offering. If "Teachers" are overrepresented in the final disbursed credit list of clients, we conclude that the reason of their disproportional representation can only be what is mediated from their initial selection, and their final "call to action" which was the product's offering.
It is quite the opposite reason that leads a particular segment not existing or not being under-represented in the final client list. Its' "indifference" is explained by the prospects' negative answer to the product offering that will result in having no representative of the particular segment in the final list of clients.

The outcome is defined by dividing the relevant percentage enjoyed by the particular product among the same client group, by the one resulted after the completion of the campaign. As a leading example, we could use the overdraft representation before and after the execution of debt consolidation campaign. Out of 8,760 pre-selected prospects, $31.08 \%$ were overdraft holders at the time of campaign creation. At the end, out of 313 clients that had only their debt consolidation loan disbursed, the representation of overdraft increased to $64.54 \%$.

\section{SALES: OPERATIONAL EXECUTION}

At the final stage, after having "secured" both the creditworthiness and the propensity to buy of the prospects, it is important to secure the operational execution by coming to conclusions for each step of the product sales circle.

The following steps represent a standard retail banking procedure for credit related products and they refer to a branch network dominated type of banking.

Each and every step is an inevitable part of the process that intends to use the merits of each of the elements that participate to the maximum, aiming to sell most products while using the least possible

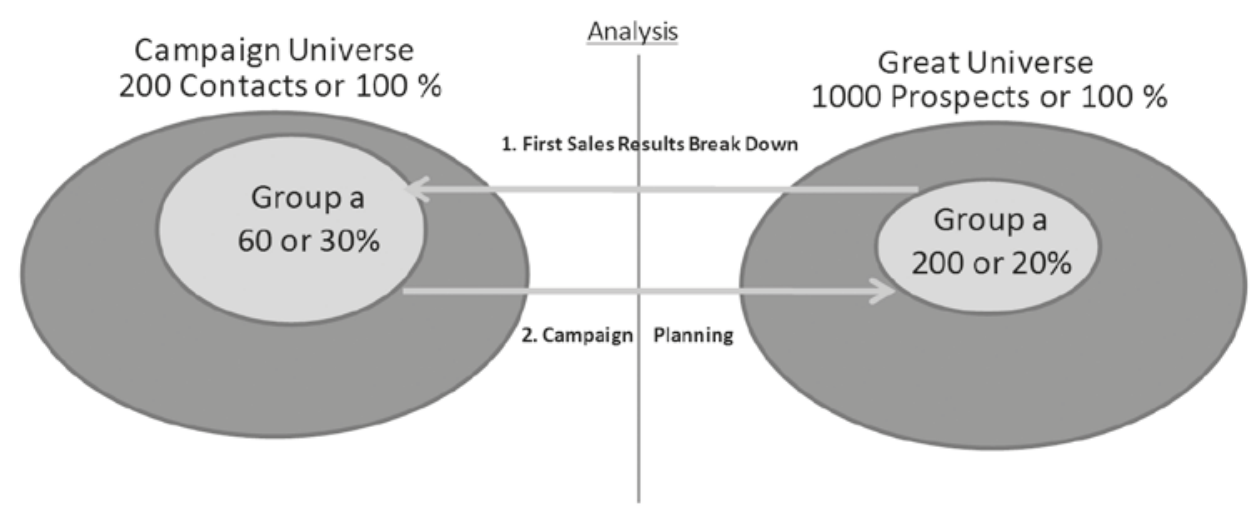

Propensity to Buy: $30 \% / 20 \%=1.50$

Group a is overrepresented $(>1)$ and therefore shows higher acceptance of communicated message.

Fuelling: $60 / 200=30 \%$

Group a has already used $30 \%$ of its potential clientele, ther efore a decision to allocated resources accordingly is anticipated.

Figure 2. Propensity to buy methodology 


\begin{tabular}{|c|c|c|c|c|c|c|}
\hline & $\begin{array}{c}\text { Contacts } \\
\text { Hits/walks in }\end{array}$ & $x$ & $\frac{\text { Response }}{\text { Contacts }}$ & $\begin{array}{r}\text { X Applications } \\
\text { Response }\end{array}$ & $\begin{array}{r}\text { Approvals } \\
\text { Applications }\end{array}$ & $\begin{array}{cc}\mathrm{x} & \text { Disbursements } \\
\text { Approvals }\end{array}$ \\
\hline & Penetration & & Response & Retrieval & Approval & Disbursement \\
\hline Depends on : & $\begin{array}{l}\text { Banked } \\
\text { Population }\end{array}$ & & $\begin{array}{l}\text { marketing } \\
\text { Awareness } \\
\text { Product } \\
\text { Competition }\end{array}$ & $\begin{array}{l}\text { Vendors } \\
\text { Organization } \\
\text { Sales Quality }\end{array}$ & $\begin{array}{l}\text { Credit Criteria } \\
\text { Segmetation } \\
\text { Orientation }\end{array}$ & Incentives \\
\hline & Success Rate & & $\begin{array}{l}\text { Disbursements } \\
\text { Hits/walks in }\end{array}$ & & & \\
\hline
\end{tabular}

Figure 3. Products sales circle

amount of resources. As each step depends on different aspects, the best coordination and prediction of behaviour based on the historic data is the ideal objective of every business manager.

The fine tuning of all sales steps is the required objective for any financial institution that aims to optimize resources and customer experience. All personalized and above-the-line campaigns that can measure branch network walk inners owe to consider the historic data series before coming to a final decision.

\section{CONCLUSIONS-PROPENSITY TO BUY AND OPERATIONAL EXECUTION}

The "propensity to buy" analysis performed on a sample of 33,021 clients through 24 different campaigns proved that both consumer and housing loan holders present a relative high promptness only to credit cards offering. In the case of housing loan holders, the explanation lies with the new needs created after the property purchase and the relatively low DTI ratio (debt to income) burden of credit cards to credit bureau. It is acceptable though from such client category to serve their needs even at a higher cost as their already used DTI ratio does not allow further exposure to standard amortized products. The consumer loan holders demonstrate behaviour similar to the cash loan holders and overdraft/credit cards. For them, extending the credit burden at a higher level, both interest rate wise and product's nature wise (see revolving $v s$. standard amortized one) does not seem to be a preventing factor.

The following four tables present the analytical results. The cells marked in grey colour in Table 5 display the client categories over-represented, i.e. indicating a higher propensity to buy for the particular product offer.
The analysis of sales operational execution also proved interesting behavioural patterns. The most obvious one is that the higher the response rate, the higher the commitment of the prospects to deliver the full documentation for credit assessment.

The cash loans (19.07\%) and the credit cards $(16.58 \%)$ are the leaders in response rate followed by proportionally high retrieval rates of $48.41 \%$ and $40.19 \%$, respectively.

Unlike common sense that would suggest higher response and retrieval rates for prospects aiming for debt consolidation loans, this is not the case. The well-established opinion that the existing creditors would react higher than anybody else to the call for reducing their monthly credit obligations is not only supported by the relative low percentage of response rate $(14.9 \%)$, but also by the respective retrieval one that cannot reach more than $34.37 \%$.

It is important to state that the initial hypothesis that customers will behave based on the standard patterns following the pre-defined calculation methodology proved to be correct to a great extent.

The findings were threefold. Firstly, securing that Serbia is strategically still a "place to be" for retail banking business as a descent part of the population is "bankable"; secondly, identifying the particular segments of customers with the higher inclination to answer positively to a new product offering; thirdly, focusing on those that have the highest probability to reach the final credit approval stage.

Different segments were identified and crosschecked for their behaviour over different products offers. We shall try to summarize by concluding that the existing cash loans and credit card holders are not price sensitive and intend to increase enormously their current credit exposure. It is also the case that 


\begin{tabular}{|c|c|c|c|c|c|c|c|c|c|}
\hline \multirow{2}{*}{$\begin{array}{c}\text { Campaign } \\
\text { no }\end{array}$} & \multirow{2}{*}{ Product Type } & \multirow{2}{*}{$\begin{array}{l}\text { Uploaded No } \\
\text { in campaign }\end{array}$} & \multicolumn{7}{|c|}{ Product mix before BTL } \\
\hline & & & Debts Con. & Car & Cash & Consumer & Housing & Overdraft & $\mathrm{CC}$ \\
\hline & All in One & 8760 & 2508 & 93 & 3915 & 342 & 965 & 2723 & 3936 \\
\hline 1 & BTL Debts Cons. J13 & 2327 & 168 & 32 & 823 & 80 & 871 & 635 & 1206 \\
\hline 2 & BTL Debts Cons. M14 & 2300 & 584 & 27 & 1197 & 82 & 47 & 615 & 932 \\
\hline 3 & BTL Debts Cons. Ap14 & 1028 & 1028 & 1 & 470 & 47 & 17 & 508 & 421 \\
\hline 4 & BTL Debts Cons. J14 & 941 & 122 & 10 & 206 & 16 & 30 & 401 & 487 \\
\hline \multirow[t]{2}{*}{5} & BTL Debts Cons. S14 & 2164 & 606 & 23 & 1219 & 117 & 0 & 564 & 890 \\
\hline & Cash & 10921 & 1556 & 107 & 5839 & 852 & 305 & 3388 & 4560 \\
\hline 6 & Alpha Cash GS & 2269 & 653 & 43 & 1148 & 89 & 155 & 1127 & 1489 \\
\hline 7 & BTL Kes 1 & 621 & 39 & 5 & 551 & 48 & 16 & 210 & 221 \\
\hline 8 & BTL Kes 2 & 532 & 40 & 2 & 473 & 45 & 4 & 129 & 150 \\
\hline 9 & BTL Kes 3 & 882 & 78 & 3 & 783 & 65 & 10 & 246 & 247 \\
\hline 10 & BTL Kes 4 & 645 & 82 & 4 & 579 & 40 & 4. & 183 & 196 \\
\hline 11 & BTL Kes 5 & 752 & 85 & 4 & 663 & 54 & 8 & 295 & 230 \\
\hline 12 & BTL Kes 6 & 363 & 69 & 6 & 267 & 60 & 9 & 147 & 105 \\
\hline 13 & BTL Kes 8 & 803 & 102 & 9 & 282 & 70 & 19 & 277 & 283 \\
\hline 14 & BTL Kes 9 & 501 & 74 & 6 & 187 & 95 & 9 & 119 & 98 \\
\hline 15 & BTL Cash & 413 & 40 & 0 & 240 & 32 & 3 & 130 & 112 \\
\hline 16 & BTL Keš 10 & 828 & 75 & 7 & 241 & 69 & 18 & 187 & 220 \\
\hline 17 & BTL Keš 12 & 593 & 72 & 2 & 253 & 122 & 14 & 145 & 112 \\
\hline 18 & BTL Keš 13 & 719 & 69 & 6 & 166 & 45 & 9 & 185 & 289 \\
\hline \multirow[t]{2}{*}{19} & BTL Vacations Cash & 1000 & 78 & 10 & 6 & 18 & 27 & 8 & 808 \\
\hline & Overdraft & 6652 & 524 & 97 & 1280 & 140 & 6 & 172 & 2405 \\
\hline 20 & BTL Overdraft M13 & 3778 & 509 & 92 & 1258 & 136 & 3 & 170 & 2372 \\
\hline \multirow[t]{2}{*}{21} & BTL Overdraft A14 & 2874 & 15 & 5 & 22 & 4 & 3 & 2 & 33 \\
\hline & $\mathrm{CC}$ & 6688 & 492 & 41 & 1738 & 144 & 109 & 2153 & 1928 \\
\hline 22 & BTL CC Dina M14 & 1500 & 77 & 5 & 259 & 19 & 3 & 343 & 214 \\
\hline 23 & BTL CC Dina S14 & 2136 & 171 & 14 & 615 & 68 & 11 & 586 & 616 \\
\hline 24 & BTL CC Visa Classic & 3052 & 244 & 22 & 864 & 57 & 95 & 1224 & 1098 \\
\hline
\end{tabular}

Tables 2. Before the campaign commences analysis (numeric)

\begin{tabular}{|c|c|c|c|c|c|c|c|c|c|}
\hline \multirow{2}{*}{$\begin{array}{c}\text { Campaign } \\
\text { no }\end{array}$} & \multirow{2}{*}{ Product Type } & \multirow{2}{*}{$\begin{array}{c}\text { Uploaded } \% \text { in } \\
\text { Campaign } \\
\end{array}$} & \multicolumn{7}{|c|}{ Product mix before $\mathrm{BTL}$} \\
\hline & & & Debts Con. & Car & Cash & Consumer & Housing & Overdraft & $\mathrm{CC}$ \\
\hline & All in One & $100.00 \%$ & $28.63 \%$ & $1.06 \%$ & $44.69 \%$ & $3.90 \%$ & $11.02 \%$ & $31.08 \%$ & $44.93 \%$ \\
\hline 1 & BTL Debts Cons. J13 & $100 \%$ & $7.22 \%$ & $1.38 \%$ & $35.37 \%$ & $3.44 \%$ & $37.43 \%$ & $27.29 \%$ & $51.83 \%$ \\
\hline 2 & BTL Debts Cons. M14 & $100 \%$ & $25.39 \%$ & $1.17 \%$ & $52.04 \%$ & $3.57 \%$ & $2.04 \%$ & $26.74 \%$ & $40.52 \%$ \\
\hline 3 & BTL Debts Cons. Ap14 & $100 \%$ & $100.00 \%$ & $0.10 \%$ & $45.72 \%$ & $4.57 \%$ & $1.65 \%$ & $49.42 \%$ & $40.95 \%$ \\
\hline 4 & BTL Debts Cons. J14 & $100 \%$ & $12.96 \%$ & $1.06 \%$ & $21.89 \%$ & $1.70 \%$ & $3.19 \%$ & $42.61 \%$ & $51.75 \%$ \\
\hline \multirow[t]{2}{*}{5} & BTL Debts Cons. S14 & $100 \%$ & $28.00 \%$ & $1.06 \%$ & $56.33 \%$ & $5.41 \%$ & $0.00 \%$ & $26.06 \%$ & $41.13 \%$ \\
\hline & Cash & $100 \%$ & $14.25 \%$ & $0.98 \%$ & $53.47 \%$ & $7.80 \%$ & $2.79 \%$ & $31.02 \%$ & $41.75 \%$ \\
\hline 6 & Alpha Cash GS & $100 \%$ & $28.78 \%$ & $1.90 \%$ & $50.59 \%$ & $3.92 \%$ & $6.83 \%$ & $49.67 \%$ & $65.62 \%$ \\
\hline 7 & BTL Kes 1 & $100 \%$ & $6.28 \%$ & $0.81 \%$ & $88.73 \%$ & $7.73 \%$ & $2.58 \%$ & $33.82 \%$ & $35.59 \%$ \\
\hline 8 & BTL Kes 2 & $100 \%$ & $7.52 \%$ & $0.38 \%$ & $88.91 \%$ & $8.46 \%$ & $0.75 \%$ & $24.25 \%$ & $28.20 \%$ \\
\hline 9 & BTL Kes 3 & $100 \%$ & $8.84 \%$ & $0.34 \%$ & $88.78 \%$ & $7.37 \%$ & $1.13 \%$ & $27.89 \%$ & $28.00 \%$ \\
\hline 10 & BTL Kes 4 & $100 \%$ & $12.71 \%$ & $0.62 \%$ & $89.77 \%$ & $6.20 \%$ & $0.62 \%$ & $28.37 \%$ & $30.39 \%$ \\
\hline 11 & BTL Kes 5 & $100 \%$ & $11.30 \%$ & $0.53 \%$ & $88.16 \%$ & $7.18 \%$ & $1.06 \%$ & $39.23 \%$ & $30.59 \%$ \\
\hline 12 & BTL Kes 6 & $100 \%$ & $19.01 \%$ & $1.65 \%$ & $73.55 \%$ & $16.53 \%$ & $2.48 \%$ & $40.50 \%$ & $28.93 \%$ \\
\hline 13 & BTL Kes 8 & $100 \%$ & $12.70 \%$ & $1.12 \%$ & $35.12 \%$ & $8.72 \%$ & $2.37 \%$ & $34.50 \%$ & $35.24 \%$ \\
\hline 14 & BTL Kes 9 & $100 \%$ & $14.77 \%$ & $1.20 \%$ & $37.33 \%$ & $18.96 \%$ & $1.80 \%$ & $23.75 \%$ & $19.56 \%$ \\
\hline 15 & BTL Cash & $100 \%$ & $9.69 \%$ & $0.00 \%$ & $58.11 \%$ & $7.75 \%$ & $0.73 \%$ & $31.48 \%$ & $27.12 \%$ \\
\hline 16 & BTL Keš 10 & $100 \%$ & $9.06 \%$ & $0.85 \%$ & $29.11 \%$ & $8.33 \%$ & $2.17 \%$ & $22.58 \%$ & $26.57 \%$ \\
\hline 17 & BTL Keš 12 & $100 \%$ & $12.14 \%$ & $0.34 \%$ & $42.66 \%$ & $20.57 \%$ & $2.36 \%$ & $24.45 \%$ & $18.89 \%$ \\
\hline 18 & BTL Keš 13 & $100 \%$ & $9.60 \%$ & $0.83 \%$ & $23.09 \%$ & $6.26 \%$ & $1.25 \%$ & $25.73 \%$ & $40.19 \%$ \\
\hline \multirow[t]{2}{*}{19} & BTL Vacations Cash & $100 \%$ & $7.80 \%$ & $1.00 \%$ & $0.60 \%$ & $1.80 \%$ & $2.70 \%$ & $0.80 \%$ & $80.80 \%$ \\
\hline & Overdraft & $100 \%$ & $7.88 \%$ & $1.46 \%$ & $19.24 \%$ & $2.10 \%$ & $0.09 \%$ & $2.59 \%$ & $36.15 \%$ \\
\hline 20 & BTL Overdraft M13 & $100 \%$ & $13.47 \%$ & $2.44 \%$ & $33.30 \%$ & $3.60 \%$ & $0.08 \%$ & $4.50 \%$ & $62.78 \%$ \\
\hline \multirow[t]{2}{*}{21} & BTL Overdraft A14 & $100 \%$ & $0.52 \%$ & $0.17 \%$ & $0.77 \%$ & $0.14 \%$ & $0.10 \%$ & $0.07 \%$ & $1.15 \%$ \\
\hline & $\mathrm{CC}$ & $100 \%$ & $7.36 \%$ & $0.61 \%$ & $25.99 \%$ & $2.15 \%$ & $1.63 \%$ & $32.19 \%$ & $28.83 \%$ \\
\hline 22 & BTL CCDina M14 & $100 \%$ & $5.13 \%$ & $0.33 \%$ & $17.27 \%$ & $1.27 \%$ & $0.20 \%$ & $22.87 \%$ & $14.27 \%$ \\
\hline 23 & BTL CCDina S14 & $100 \%$ & $8.01 \%$ & $0.66 \%$ & $28.79 \%$ & $3.18 \%$ & $0.51 \%$ & $27.43 \%$ & $28.84 \%$ \\
\hline 24 & BTL CC Visa Classic & $100 \%$ & $7.99 \%$ & $0.72 \%$ & $28.31 \%$ & $1.87 \%$ & $3.11 \%$ & $40.10 \%$ & $35.98 \%$ \\
\hline
\end{tabular}

Tables 3. Before the campaign commences analysis (percentage)

their intentions are not time-limited to accept verbally the new product offer, but they will demonstrate committment to it by showing to be very determined to deliver all required documentation for credit assessment.
Given that both products enjoy one of the highest nominal interest rates in the Serbian market, it is not unusual that they have become the most wanted segments triggering banks to argue over them. 


\begin{tabular}{|c|c|c|c|c|c|c|c|c|c|}
\hline \multirow{2}{*}{$\begin{array}{c}\text { Campaign } \\
\text { no }\end{array}$} & \multirow{2}{*}{ Product Type } & \multirow{2}{*}{$\begin{array}{l}\text { Approved No } \\
\text { in campaign }\end{array}$} & \multicolumn{7}{|c|}{ Product mix after BTL (approved) } \\
\hline & & & Debts Con! & Car & Cash & Consumer & Housing & Overdraft & $\mathrm{CC}$ \\
\hline & All in One & 313 & 313 & 0 & 77 & 8 & 11 & 202 & 173 \\
\hline 1 & BTL Debts Cons. J13 & 50 & 50 & 0 & 19 & 2 & 7 & 24 & 24 \\
\hline 2 & BTL Debts Cons. M14 & 23 & 23 & 0 & 3 & 0 & 0 & 13 & 17 \\
\hline 3 & BTL Debts Cons. Ap14 & 149 & 149 & 0 & 29 & 3 & 1 & 111 & 82 \\
\hline 4 & BTL Debts Cons. J14 & 37 & 37 & 0 & 7 & 1 & 3 & 26 & 19 \\
\hline 5 & BTL Debts Cons. S14 & 54 & 54 & 0 & 19 & 2 & 0 & 28 & 31 \\
\hline & Cash & 761 & 138 & 5 & 761 & 24 & 8 & 426 & 362 \\
\hline 6 & Alpha Cash GS & 100 & 34 & 3 & 100 & 5 & 3 & 65 & 62 \\
\hline 7 & BTL Kes 1 & 63 & 18 & 1 & 63 & 2 & 0 & 43 & 29 \\
\hline 8 & BTL Kes 2 & 68 & 10 & 0 & 68 & 0 & 1 & 26 & 29 \\
\hline 9 & BTL Kes 3 & 131 & 26 & 0 & 131 & 1 & 1 & 70 & 56 \\
\hline 10 & BTL Kes 4 & 51 & 5 & 1 & 51 & 3 & 0 & 25 & 22 \\
\hline 11 & BTL Kes 5 & 63 & 11 & 0 & 63 & 2 & 1 & 40 & 25 \\
\hline 12 & BTL Kes 6 & 38 & 8 & 0 & 38 & 2 & 1 & 20 & 10 \\
\hline 13 & BTL Kes 8 & 30 & 3 & 0 & 30 & 2 & 0 & 17 & 18 \\
\hline 14 & BTL Kes 9 & 20 & 0 & 0 & 20 & 0 & 0 & 8 & 7 \\
\hline 15 & BTL Cash & 47 & 10 & 0 & 47 & 0 & 0 & 29 & 17 \\
\hline 16 & BTL Keš 10 & 50 & 3 & 0 & 50 & 2 & 0 & 31 & 29 \\
\hline 17 & BTL Keš 12 & 30 & 4 & 0 & 30 & 2 & 0 & 18 & 11 \\
\hline 18 & BTL Keš 13 & 43 & 3 & 0 & 43 & 3 & 1 & 26 & 23 \\
\hline 19 & BTL Vacations Cash & 27 & 3 & 0 & 27 & 0 & 0 & 8 & 24 \\
\hline & Overdraft & 198 & 21 & 2 & 60 & 3 & 0 & 198 & 103 \\
\hline 20 & BTL Overdraft M13 & 142 & 21 & 2 & 47 & 3 & 0 & 142 & 87 \\
\hline 21 & BTL Overdraft A14 & 56 & 0 & 0 & 13 & 0 & 의 & 56 & 16 \\
\hline & $\mathrm{CC}$ & 333 & 48 & 1 & 93 & 15 & 6 & 209 & 333 \\
\hline 22 & BTL CC Dina M14 & 68 & 7 & 0 & 20 & 2 & 요 & 34 & 68 \\
\hline 23 & BTL CC Dina S14 & 207 & 21 & 1 & 47 & 10 & 1 & 128 & 207 \\
\hline 24 & BTL CC Visa Classic & 58 & 20 & 0 & 26 & 3 & 5 & 47 & 58 \\
\hline
\end{tabular}

Tables 4. After the campaign ends analysis (numeric)

\begin{tabular}{|c|c|c|c|c|c|c|c|c|c|}
\hline \multirow{2}{*}{$\begin{array}{c}\text { Campaign } \\
\text { no }\end{array}$} & & \multirow{2}{*}{$\begin{array}{l}\text { Approved \% } \\
\text { in campaign }\end{array}$} & \multicolumn{7}{|c|}{ Product mix after BTL (approved) } \\
\hline & & & Debts Con. & Car & Cash & Consumer & Housing & Overdraft & $\mathrm{CC}$ \\
\hline & All in One & $100.00 \%$ & $100.00 \%$ & $0.00 \%$ & $24.60 \%$ & $2.56 \%$ & $3.51 \%$ & $64.54 \%$ & $55.27 \%$ \\
\hline 1 & BTL Debts Cons. J13 & $100.00 \%$ & $100.00 \%$ & $0.00 \%$ & $38.00 \%$ & $4.00 \%$ & $14.00 \%$ & $48.00 \%$ & $48.00 \%$ \\
\hline 2 & BTL Debts Cons. M14 & $100.00 \%$ & $100.00 \%$ & $0.00 \%$ & $13.04 \%$ & $0.00 \%$ & $0.00 \%$ & $56.52 \%$ & $73.91 \%$ \\
\hline 3 & BTL Debts Cons. Ap14 & $100.00 \%$ & $100.00 \%$ & $0.00 \%$ & $19.46 \%$ & $2.01 \%$ & $0.67 \%$ & $74.50 \%$ & $55.03 \%$ \\
\hline 4 & BTL Debts Cons. J14 & $100.00 \%$ & $100.00 \%$ & $0.00 \%$ & $18.92 \%$ & $2.70 \%$ & $8.11 \%$ & $70.27 \%$ & $51.35 \%$ \\
\hline \multirow[t]{2}{*}{5} & BTL Debts Cons. S14 & $100.00 \%$ & $100.00 \%$ & $0.00 \%$ & $35.19 \%$ & $3.70 \%$ & $0.00 \%$ & $51.85 \%$ & $57.41 \%$ \\
\hline & Cash & $100.00 \%$ & $18.13 \%$ & $0.66 \%$ & $100.00 \%$ & $3.15 \%$ & $1.05 \%$ & $55.98 \%$ & $47.57 \%$ \\
\hline 6 & Alpha Cash GS & $100.00 \%$ & $34.00 \%$ & $3.00 \%$ & $100.00 \%$ & $5.00 \%$ & $3.00 \%$ & $65.00 \%$ & $62.00 \%$ \\
\hline 7 & BTL Kes 1 & $100.00 \%$ & $28.57 \%$ & $1.59 \%$ & $100.00 \%$ & $3.17 \%$ & $0.00 \%$ & $68.25 \%$ & $46.03 \%$ \\
\hline 8 & BTL Kes 2 & $100.00 \%$ & $14.71 \%$ & $0.00 \%$ & $100.00 \%$ & $0.00 \%$ & $1.47 \%$ & $38.24 \%$ & $42.65 \%$ \\
\hline 9 & BTL Kes 3 & $100.00 \%$ & $19.85 \%$ & $0.00 \%$ & $100.00 \%$ & $0.76 \%$ & $0.76 \%$ & $53.44 \%$ & $42.75 \%$ \\
\hline 10 & BTL Kes 4 & $100.00 \%$ & $9.80 \%$ & $1.96 \%$ & $100.00 \%$ & $5.88 \%$ & $0.00 \%$ & $49.02 \%$ & $43.14 \%$ \\
\hline 11 & BTL Kes 5 & $100.00 \%$ & $17.46 \%$ & $0.00 \%$ & $100.00 \%$ & $3.17 \%$ & $1.59 \%$ & $63.49 \%$ & $39.68 \%$ \\
\hline 12 & BTL Kes 6 & $100.00 \%$ & $21.05 \%$ & $0.00 \%$ & $100.00 \%$ & $5.26 \%$ & $2.63 \%$ & $52.63 \%$ & $26.32 \%$ \\
\hline 13 & BTL Kes 8 & $100.00 \%$ & $10.00 \%$ & $0.00 \%$ & $100.00 \%$ & $6.67 \%$ & $0.00 \%$ & $56.67 \%$ & $60.00 \%$ \\
\hline 14 & BTL Kes 9 & $100.00 \%$ & $0.00 \%$ & $0.00 \%$ & $100.00 \%$ & $0.00 \%$ & $0.00 \%$ & $40.00 \%$ & $35.00 \%$ \\
\hline 15 & BTL Cash & $100.00 \%$ & $21.28 \%$ & $0.00 \%$ & $100.00 \%$ & $0.00 \%$ & $0.00 \%$ & $61.70 \%$ & $36.17 \%$ \\
\hline 16 & BTL Keš 10 & $100.00 \%$ & $6.00 \%$ & $0.00 \%$ & $100.00 \%$ & $4.00 \%$ & $0.00 \%$ & $62.00 \%$ & $58.00 \%$ \\
\hline 17 & BTL Keš 12 & $100.00 \%$ & $13.33 \%$ & $0.00 \%$ & $100.00 \%$ & $6.67 \%$ & $0.00 \%$ & $60.00 \%$ & $36.67 \%$ \\
\hline 18 & BTL Keš 13 & $100.00 \%$ & $6.98 \%$ & $0.00 \%$ & $100.00 \%$ & $6.98 \%$ & $2.33 \%$ & $60.47 \%$ & $53.49 \%$ \\
\hline \multirow[t]{2}{*}{19} & BTL Vacations Cash & $100.00 \%$ & $11.11 \%$ & $0.00 \%$ & $100.00 \%$ & $0.00 \%$ & $0.00 \%$ & $29.63 \%$ & $88.89 \%$ \\
\hline & Overdraft & $100.00 \%$ & $10.61 \%$ & $1.01 \%$ & $30.30 \%$ & $1.52 \%$ & $0.00 \%$ & $100.00 \%$ & $52.02 \%$ \\
\hline 20 & BTL Overdraft M13 & $100.00 \%$ & $14.79 \%$ & $1.41 \%$ & $33.10 \%$ & $2.11 \%$ & $0.00 \%$ & $100.00 \%$ & $61.27 \%$ \\
\hline \multirow[t]{2}{*}{21} & BTL Ove rdraft A14 & $100.00 \%$ & $0.00 \%$ & $0.00 \%$ & $23.21 \%$ & $0.00 \%$ & $0.00 \%$ & $100.00 \%$ & $28.57 \%$ \\
\hline & $\mathrm{CC}$ & $100.00 \%$ & $14.41 \%$ & $0.30 \%$ & $27.93 \%$ & $4.50 \%$ & $1.80 \%$ & $62.76 \%$ & $100.00 \%$ \\
\hline 22 & BTL CC Dina M14 & $100.00 \%$ & $10.29 \%$ & $0.00 \%$ & $29.41 \%$ & $2.94 \%$ & $0.00 \%$ & $50.00 \%$ & $100.00 \%$ \\
\hline 23 & BTL CC Dina S14 & $100.00 \%$ & $10.14 \%$ & $0.48 \%$ & $22.71 \%$ & $4.83 \%$ & $0.48 \%$ & $61.84 \%$ & $100.00 \%$ \\
\hline 24 & BTL CC Visa Classic & $100.00 \%$ & $34.48 \%$ & $0.00 \%$ & $44.83 \%$ & $5.17 \%$ & $8.62 \%$ & $81.03 \%$ & $100.00 \%$ \\
\hline
\end{tabular}

Tables 5. After the campaign ends analysis (percentage)

\section{REFERENCES}

Ajzen, I. (1991). Theory of planned behaviour. Organizational Behavior and Human Decision Processes. 50, 179-211.

Ajzen, I. (2000). The theory of planned behavior: Habit, perceived control, and reasoned action. Mannheim: Mannheimer Zentrum für Europäische Sozialforschung.
Ajzen, I. (2008). Consumer attitudes and behavior. In C. P. Haugtvedt, P. M. Herr, \& F. R. Cardes (Ed.) Handbook of Consumer Psychology (pp. 525-548). New York: Lawrence Erlbaum Associates

Ajzen, I., \& Fishbein, M. (2002). Understanding attitudes and predicting social behavior. Upper Saddle River, NJ: Prentice-Hall. 
Armitage, C.J., \& Conner, M. (2001). Efficacy of the theory of planned behaviour: A meta-analytic review. British Journal of Social Psychology. 40(4), 471-499. DOI: $10.1348 / 014466601164939$

Brassington, F., Pettitt, S., \& McMillan, K. (2010). Principles of marketing. Harlow: Financial Times Prentice Hall.

Campbell, D. T., \& Russo, M. J. (2001). Social measurement. London: SAGE.

Conner, M., \& Armitage, C.J. (2001). Extending the Theory of Planned Behavior: A meta-analytic review. British Journal of Social Psychology. 40(4), 471-499. DOI: 10.1348/014466601164939

Farr, R. (1994). Attitudes, social representations and social attitudes. Papers on Social Representations. 3(1), 30-33.

Fishbein, M. (1979). A theory of reasoned action: Some applications and implications. Nebraska Symposium on Motivation. 27, 65-116.

Fishbein, M., \& Ajzen, I. (2010). Predicting and changing behavior: The reasoned action approach. New York: Psychology Press.

Godin, G., \& Kok, G. (1996). The theory of planned behaviour: A review of its applications in health related behaviours. American Journal of Health Promotion. 11(2), 87-98.
Kumar, A. (2013). Bank Marketing Mix in today banking sector. BPR Technologia: A Journal of Science, Technology \& Management. 2(1), 17-26.

Miller, G.A. (1956). The Magical Number Seven, Plus or Minus Two. Psychological Review. 101(2), 343-352

Muller, C., \& Nordman, C.J. (2004). Which Human Capital Matters for Rich and Poor's Wages? Evidence from Matched Worker-Firm Data from Tunisia. DIAL Working Paper No. DT/2004/09. DOI: 10.2139/ssrn.652941

Raz, J. (2010). Engaging reason: On the theory of value and action. Oxford: Oxford University Press.

Read, S.J., \& Miller, L.C. (2014). Connectionist Models of Social Reasoning and Social Behavior. Hoboken: Taylor and Francis.

Rose, P.S., \& Hudgins, S.C. (2013). Bank management \& financial services. New York: McGraw-Hill.

Storbacka, K., \& Nenonen, S. (2014). Learning with the market: Facilitating market innovation. Industrial Marketing Management. 44, 73-82. DOI:10.1016/j.indmarman.2014.10.009

Storbacka, K., \& Pennanen, R. (2014). Solution business: Building a platform for organic growth. Cham: Springer.

\section{PREDVIĐANJE PONAŠANJA FIZIČKIH LICA KAO KORISNIKA USLUGA U BANKARSKOM SEKTORU NA OSNOVU STATISTIKE}

\section{Rezime:}

Cilj bilo koje ekonomske aktivnost, a naročito finansijske, jeste stvaranje potreba. Kako finansijske aktivnosti nisu izuzetak tome, primarni cilj bilo koje finansijske institucije jeste razumevanje i zadovoljavanje potreba klijenata. Veoma je važno da finansijske ustanove budu upoznate sa detaljima vezanim za ponašanje klijenata i procesima koji utiču na klijente pri donošenju odluke. Na taj način će se zadovoljiti ne samo potrebe klijenata, već i pridobiti lojalnost klijenata, i uspostaviti dobri dugoročni odnosi sa njima. Kao i svaki drugi, odnos između klijenta i banke trebalo bi da bude zasnovan na uzajamnoj podršci i razumevanju. Imajući u vidu bankarsko tržište za fizička lica (retail market) u Srbiji, mogu se izvesti sledeći zaključci: prvo, da i dalje postoji veliki potencijal za poslovanje u ovom domenu; drugo, da je određeni deo klijenata voljan da prihvati nove proizvode, i treće, da banke moraju da obrate posebnu pažnju na klijente sa najvećom kreditnom sposobnošću. Što se tiče odnosa klijenata prema različitim ponudama proizvoda, možemo zaključiti da korisnici gotovinskih kredita i korisnici kreditnih kartica nisu cenovno osetljivi, te da stoga postojeći korisnici teže povećanju svoje kreditne izloženosti (zaduženosti).

\section{Ključne reči:}

bankarstvo za fizička lica (retail banking), ponašanje klijenata, segmentacija, lojalnost.

Received: February 15, 2015. Correction: March 22, 2015. Accepted: April 15, 2015. 